\title{
Impact of a drug dispensing model at a Community Pharmacy in Goiânia, Goiás, Brazil
}

\author{
Tatyana Xavier Almeida Matteucci Ferreira ${ }^{1 *}$, Luciana Resende Prudente ${ }^{2}$, \\ Nathalie de Lourdes Souza Dewulf ${ }^{3}$, Mércia Pandolfo Provin ${ }^{3}$, Thaissa Costa Cardoso ${ }^{4}$, \\ Érika Aparecida da Silveira ${ }^{5}$, Rita Goreti Amaral ${ }^{3}$
}

\author{
${ }^{1}$ Clinical Hospital, Federal University of Goias, Goiânia, Brazil, ${ }^{2}$ Santa Casa Hospital, Goiânia, Brazil, ${ }^{3}$ School of \\ Pharmacy, Federal University of Goias, Goiânia, Brazil, ${ }^{4}$ União de Goyazes Faculty, Goiânia, Brazil, ${ }^{5}$ School of Medicine, \\ Pos-graduation Program in Health Sciences, Federal University of Goias, Goiânia, Brazil
}

\begin{abstract}
Although dispensing of medication has been addressed by theoretical models, studies that confirm the impact of this service are still needed. The objective was to evaluate the impact of a new model of medicine dispensing system on patients' medication knowledge, adherence to treatment and satisfaction. One hundred and four patients attending the dispensing service of a community pharmacy between 21 January 2013 and 20 April 2013 were included in this intervention study. The impact of the service on patients' medication knowledge, adherence to treatment and satisfaction was assessed by using validated questionnaires at two time points: at the moment of medication dispensing and 30 days thereafter by telephone contact. Statistical analysis was performed by McNemar's test, and a $p<0.05$ was set as statistically significant. The number of patients showing insufficient knowledge about medications decreased by $50 \%(\mathrm{p}<0.05)$, and the number of those showing sufficient knowledge was three times greater $(\mathrm{p}<0.05)$ after medicine dispensing. A high level of satisfaction was observed. Improvement of medication adherence, however, was not observed. The proposed system model for drug dispensing improved patients' knowledge about medication and satisfaction.
\end{abstract}

Keywords: Community Pharmacy Services. Outcome Assessment (Health Care). Pharmacies. Patient Medication Knowledge. Patient Satisfaction. Brazil.

\section{INTRODUCTION}

In Brazil, similarly to European countries, medicine dispensing is a pharmaceutical practice that comprises dispensing of medication and counseling of patients (Brasil, 1998).

The main objective of drug dispensing practices is to promote an appropriate use of medications and to achieve the expected therapeutic success. They should consider cognitive aspects involved of prescription interpretation and provide the patients with individual guidance. (Angonesi, 2008; Foro de Atención Farmacéutica, 2007).

Several authors from Brazil and countries such as Portugal and Spain have proposed system models for

\footnotetext{
*Correspondence: T. X. A. M. Ferreira. Grupo de estudo e pesquisa em Assistência Farmacêutica e Atenção à Saúde - NAF-SAUDE, Faculdade de Farmácia, Universidade Federal de Goiás. Rua 240, esquina com $5^{\text {a }}$ Avenida, s/n, Setor Leste Universitário. CEP: 74605-170, Goiânia/Goiás - Brasil. Telephone/ Fax: +55 62 3209-6044. E-mail: tatymatteucci@gmail.com
}

drug dispensing that include both technical and cognitive approaches (Angonesi, Rennó, 2011; Cardoso et al., 2015; Foro de Atención Farmacéutica, 2007; Foro de Atención Farmacéutica, 2008; Soares et al., 2013). However, studies on medication dispensing have mostly focused on facility conditions and processes (Becker et al., 2007; Buurma et al., 2001; Chatsisvili et al., 2010; Indermitte et al., 2007; Sánchez, 2013), and further studies that investigate the impact of drug dispensing and proposed models are still needed.

According to Farris and Kirking (1993), the assessment of pharmaceutical care services, including drug dispensing, should be based on aspects other than clinical outcomes, since the role of the pharmacist in patient's care encompasses more than clinical aspects. In addition to relieving symptoms and improving clinical parameters, the authors emphasize the importance of enhancing patients' awareness about the therapy, adherence and satisfaction with health services. 
Considering the need for understanding the impact of pharmaceutical care provided during medication dispensing on patients, this study evaluated the results of a model proposed for drug dispensing in a community pharmacy in Brazil using three outcome measures: patients' knowledge about medication, adherence to treatment and satisfaction with pharmaceutical services.

\section{METHOD}

This was an intervention study performed at the University Pharmacy of the Federal University of Goias. This study was approved by the Research Ethics Committee of the Federal University of Goias (approval number 222/2012) and participants gave written informed consent before taking part.

\section{Subjects}

Patients attending the Division of drug dispensing of the University Pharmacy of the Federal University of Goias between 21 January 2013 and 20 April 2013 were considered eligible for the study. The follow-up period was defined based on therapeutical and epidemiological data of patients, who were composed mostly of chronic disease patients, who received their medication from the University Pharmacy for a 90-day treatment period.

Inclusion criteria were attendance at the drug dispensing services, age greater than or equal to 18 years and participants' consent. Exclusion criteria were communication impairment, medication dispensed to individuals other than the patients or their caregivers, missing data in at least one evaluation time point, lack of informed consent.

\section{Setting characteristics}

In Brazil, University/Campus Pharmacies are pharmaceutical facilites aimed at drug dispensing and education, run by Pharmacy Schools (Conselho Federal de Farmácia, 2008).

Drug dispensing processes at the University Pharmacy of the Federal University of Goias (Cardoso et al., 2015; Ferreira et al., 2016) are conducted in continuing steps throughout patients receive personal and drug therapy information (Figure 1). This dispensing system model has been implemented in January 2012 in accordance with the National Policy of Pharmaceutical Assistance (Brasil, 2004), previous publications (Angonesi, Rennó, 2011; Foro de Atención Farmacéutica, 2007; Iglésias-Ferreira, 2009; Soares et al., 2013) and current legislation (Brasil, 1973; 2009; Conselho Federal de Farmácia, 2001). After implementation of the system model, standard operating procedures were established.

It is worth pointing out that, since compounding drugs are also dispensed by the pharmacy, not all steps illustrated in Figure 1 are performed in the presence of the patient. Interpretation of prescription, for example, is generally conducted in the interval between the compounding drug order and its dispensing.

Medications were dispensed to patients or their caregivers. Drug prescription was carefully examined for its comformity to Brazilian regulations (Brasil, 1973). Then, the patient was interviewed by a pharmacist regarding personal and therapy-related data: age, sex, height, weight, occupation, allergies and other chronic diseases, use of medications, smoking and drinking habits, pregnancy and lactation. Also, the pharmacist asked whether the patient was aware of the aim of the therapy, how to take the medications, and verified whether expected results of the therapy were being achieved as well as the occurrence of adverse effects. All data were stored in a dedicated software for pharmaceutical data management, Pharmacie (Pharmasoftware, 2013). Finally, the pharmacist interpreted the prescription according to the guideline proposed by the Grupo de Investigação em Cuidados Farmacêuticos da Universidade Lusófona, Portugal, (GICUF) (Iglésias-Ferreira, 2009) (Figure 2).

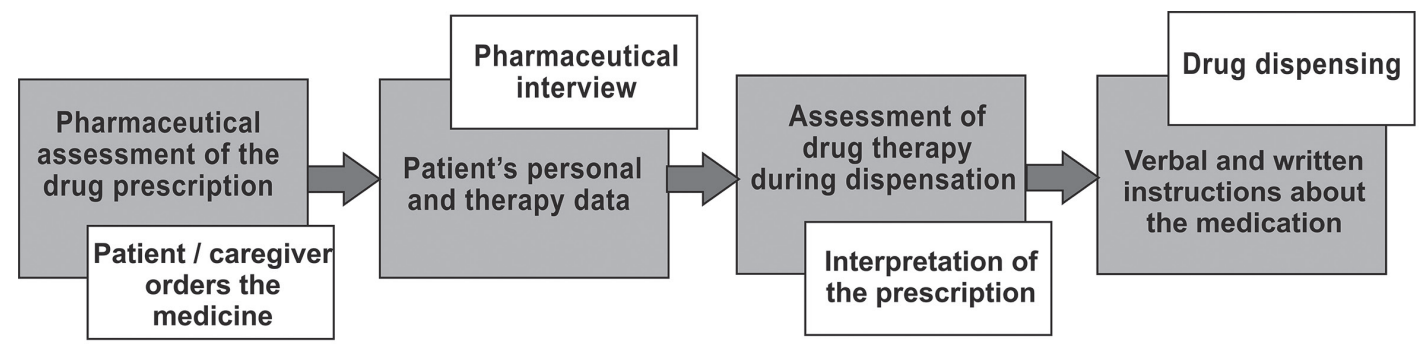

Cardoso et al., 2015

FIGURE 1 - Flowchart of drug dispensing processes routinely conducted at the University Pharmacy of the Federal University of Goias. 


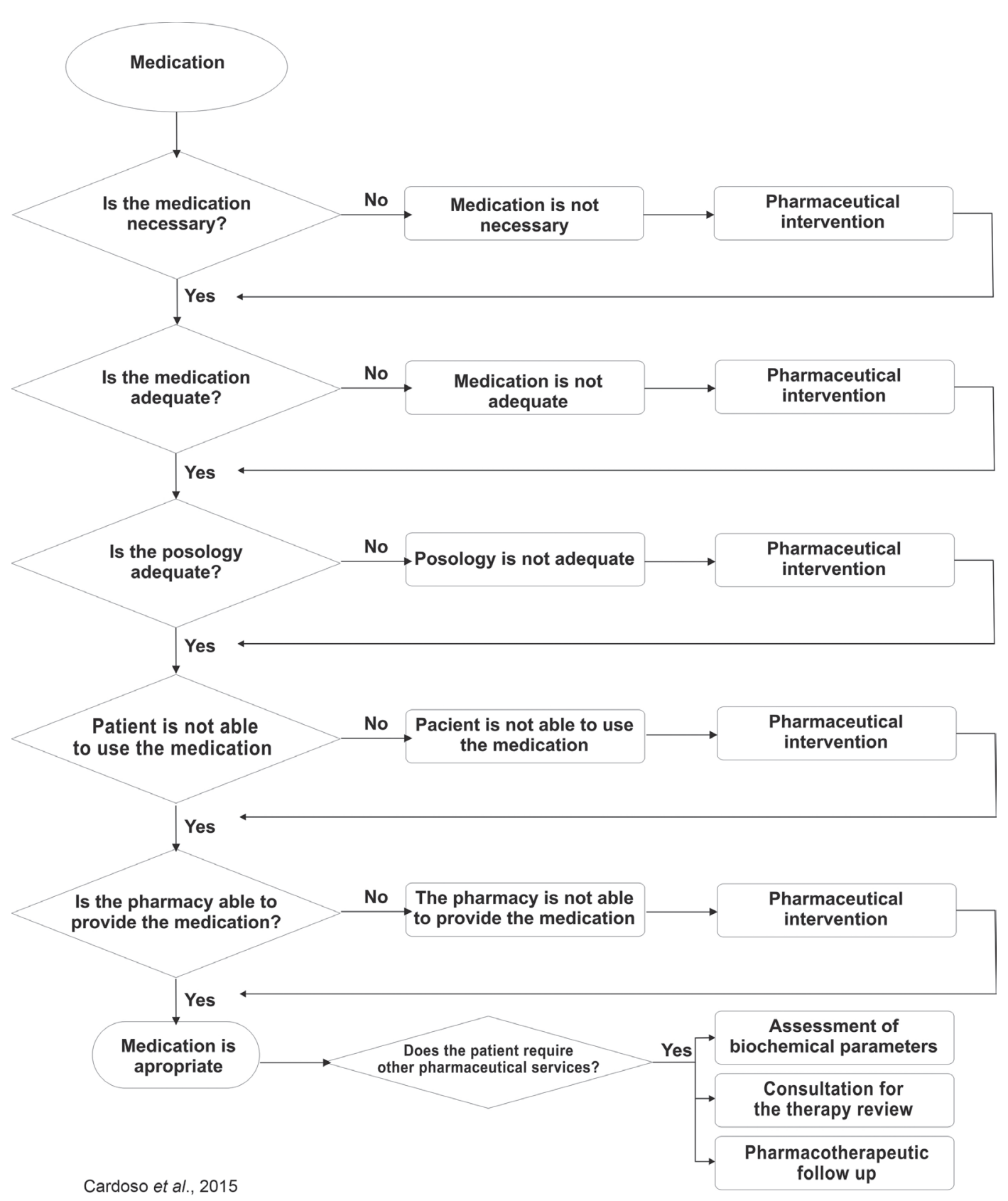

FIGURE 2 - Flowchart of the pharmacotherapy analysis at the Campus Pharmacy.

In this pharmacotherapy assessment tool, the five questions showed in the flowchart were sequentially answered regarding each medication. When a drugrelated problem was identified (i.e. when the answer to any of these questions was no"), the assessment process was discontinued and the problem-solving process was initiated. According to the pharmacist's discretion, each drug-related problem led to pharmaceutical interventions, followed by the reassessment of the therapy. These steps were successively repeated until the answers to all the questions were "yes". Interventions could be addressed to the person who made the prescription, the patient or the drug in use, in accordance with the Pharmaceutical Care Network Europe classification of drug-related problem (Version 6.2) (PCNE, 2010). At the end of the pharmacotherapy analysis, the pharmacist evaluated whether the patient required other pharmaceutical services and referred the patient when deemed necessary. All drug- related problems identified and pharmaceutical services performed were registered in appropriate registration form.

Medication was then dispensed and directions of the use were provided by the pharmacist as recommended by the International Pharmaceutical Federation (2009). Medication information was delivered orally or written. 


\section{Data collection}

Patients' profile was characterized by sex, age, marital status, type of health service attended (public or private), and complexity of pharmacotherapy, obtained from the university pharmacy database (Pharmasoftware, 2013). Complexity of pharmacotherapy was calculated using the Medication Regimen Complexity Index (Melchiors et al., 2007) and dichotomized into low ( $<7$ points) and high ( $\geq 7$ points) (Fröhlich, Pizzol, Mengue, 2010). Patient's knowledge about medication prescription and adherence behavior was assessed by appropriate questionnaires before and after the dispensing of medications, in a pretest-posttest design (Figure 3).

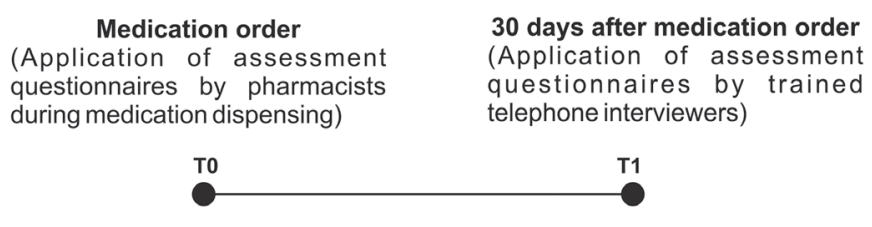

FIGURE 3 - Evaluation time points for assessing the drug dispensing service at the university pharmacy.

Thirty days after dispensing of drugs, assessment questionnaires were administered by trained interviewers (and not by the same pharmacists at T0) to prevent interviewers' bias. The most suitable time for the interview at T1 was scheduled at patients' convenience. If the patient did not answer the first telephone call, two additional attempts were made on the two following days. When the third call was not answered, the patient was excluded from the study.

Adherence behavior was assessed by the Morisky scale questionnaire (Morisky, Green, Levine, 1986), and classified as adherence or non-adherence. Non-adherence was further divided by intentional and unintentional nonadherence (Sewitch et al., 2003).

A validated questionnaire (Fröhlich, Pizzol, Mengue, 2010) was used to assess patients' knowledge about medication. When more than one medication was dispensed, the questionnaire was asked regarding the first medication listed on the prescription. The first question ("What's the name of the drug prescribed?") was excluded from the evaluation, since the interviewer had to state which medicine the patient would be asked about. Final classification score was hence adapted and appropriately corrected to this exclusion. Patients' knowledge about medication was classified in: (1) $<7$ points: insufficient (the patient cannot use medicines safely); (2) 7 9 points: moderate (the patient can use medicines safely in the absence of complications); (3) $\geq 10$ points: good (the patient can use medicines safely in any circumstances).

Patients' satisfaction with the drug dispensing service was assessed by an appropriate instrument validated in English (Larson, Rovers, MacKeigan, 2002) and translated into Portuguese (Correr et al., 2009). Patients were asked to fill in a Likert-type scale questionnaire concerning their satisfaction with the service (as 'excellent', 'very good', 'good', 'fair' or 'poor').

\section{Data analysis}

Data storage and analysis were performed using Epi Info 3.5.4 (Centers for Disease Control and Prevention, 2012) and STATA Version 12 for Windows (StataCorp, 2011). For statistical analyses, all variables were studied descriptively, by means of absolute and relative frequency calculations. Continuous variables were expressed as mean and standard deviation.

Knowledge about drug prescription and adherence was assessed before and after drug dispensing by McNemar's test. Knowledge about medication prescription was also assessed individually by chi-square and Fisher's exact test. A p-value $<0.05$ was considered to be statistically significant.

\section{RESULTS}

A total of 170 patients were included in the study. Forty-eight patients did not fill in the assessment instrument at T1, 16 patients did not return to the pharmacy for their ordered medication, and for two patients, the medication was not delivered due to issues related to the drug compounding process. A total of 104 completed the study.

A high percentage of female patients with low complexity of pharmacotherapy were observed (Table I).

Compared with T0, adherence behavior was not significantly different, however the number of nonadherent patients significantly $(\mathrm{P}=0.03)$ decreased at $\mathrm{T} 1$ (Table II).

Knowledge about drug prescription improved significantly, with a $55 \%$ reduction in the number of patients with insufficient knowledge on medications. The number of patients with good knowledge on medication was more than three times greater at $\mathrm{T} 1$ compared with T0 (Table III).

Comparative analyses of each parameter regarding knowledge revealed significant differences between $\mathrm{T} 0$ and T1 (Table IV).

Patients reported a high level of satisfaction towards the dispensing service. All categories were rated as 
TABLE I - Characteristics of patients attending the medication dispensation division at the University Pharmacy of the Federal University of Goias, $2013(\mathrm{n}=104)$

\begin{tabular}{|c|c|}
\hline Variables & n $(\%)$ \\
\hline \multicolumn{2}{|l|}{ Sex } \\
\hline Female & $84(80.8)$ \\
\hline Male & $20(19.2)$ \\
\hline \multicolumn{2}{|l|}{ Age $^{1}$} \\
\hline $18-40$ years & $29(29.9)$ \\
\hline $41-60$ years & $35(36.1)$ \\
\hline$>60$ years & $33(34.0)$ \\
\hline \multicolumn{2}{|l|}{ Marital status $^{2}$} \\
\hline Single & $39(42.9)$ \\
\hline Married & $32(35.2)$ \\
\hline Divorced & $9(9.9)$ \\
\hline Widow/er & $11(12.0)$ \\
\hline \multicolumn{2}{|l|}{ Type of health service ${ }^{3}$} \\
\hline Public & $47(54.0)$ \\
\hline Private & $40(46.0)$ \\
\hline \multicolumn{2}{|c|}{$\begin{array}{l}\text { Attendance at the division of drug } \\
\text { dispensation of the Pharmacy for } \\
\text { the first time }\end{array}$} \\
\hline Yes & $38(36.5)$ \\
\hline No & $66(63.5)$ \\
\hline \multicolumn{2}{|c|}{ Complexity of the drug therapy } \\
\hline High & $20(19.2)$ \\
\hline Low & $84(80.8)$ \\
\hline
\end{tabular}

$1 . \mathrm{n}=97 ; 2 . \mathrm{n}=91 ; 3 . \mathrm{n}=87$

excellent or very good by more than $70 \%$ of the patients, and the lowest mean rate, in a 5-point scale, was 4.3 (Table V).

\section{DISCUSSION}

This study showed that the model for drug dispensation developed and used at the University Pharmacy of the Federal University of Goias increased the knowledge about safe use of medication in the absence of treatment-related complications in nearly $80 \%$ of patients that completed the study.

Our results are in line with previous studies conducted in Brazil and India (Oenning, Oliveira, Blatt, 2011; Ponnusankar et al., 2004; Silva, Schenkel, Mengue, 2000), showing increased knowledge about medications after dispensation. In comparison with other studies in Brazil (Oenning, Oliveira, Blatt, 2011; Silva, Schenkel, Mengue, 2000), a relatively greater percentage of patients with "good" knowledge on medication after drug dispensing were found in our study, however, similarly to their findings, we did not observe increased knowledge about adverse effects, skipping of doses or mode of drug administration.

The lack of patients' awareness of drug side effects has been discussed in previous studies (Oenning, Oliveira, Blatt, 2011; Silva, Schenkel, Mengue, 2000), which tend to conclude that it may be due to the lack of evaluation by the professionals responsible for drug prescription and dispensing, and also by the patients. Drug prescribers and pharmacists tend to omit information about drug adverse effects from the patients, in attempt to prevent non-adherence to treatment or symptoms caused by autosuggestion.

Further studies describing determining factors of patients' knowledge, concerning skipping doses and mode of administration of the drugs, after receiving pharmacist's instructions are still needed. According to Margonato, Thomson and Paoliello (2008), only $23.5 \%$ of victims of unintentional drug poisoning received instructions on the correct use of medication at dispensation, as registered by a poison control center in Brazil. Lack of knowledge on medication may result in poor adherence, drug therapy failures, increased incidence of adverse effects, and aggravation of clinical conditions (Fernandes, Pires, Gouvêa, 2002; Margonato, Thomson, Paoliello, 2008; Oenning, Oliveira, Blatt, 2011). On the other

TABLE II - Patients adherence to drug therapy assessed by the Morisky scale questionnaire (Morisky< green, Levine, 1986) before and after the dispensation at the University Pharmacy of the Federal University of Goiás, $2013(\mathrm{n}=104)$

\begin{tabular}{lccc}
\hline \multirow{2}{*}{ Levels of adherence } & Before (T0) & After (T1) & \multirow{2}{*}{$\mathbf{p}^{*}$} \\
\cline { 2 - 3 } & $\mathbf{n ~ ( \% )}$ & $\mathbf{n} \mathbf{( \% )}$ & 0.81 \\
High level of adherence & $17(16.4)$ & $18(17.3)$ & \\
Low level of adherence & $87(83.6)$ & $86(82.7)$ & 0.18 \\
$\quad 18(20.7)$ & $25(29.1)$ & & 0.40 \\
$\quad$ Low unintentional adherence & $14(16.1)$ & $17(19.8)$ & 0.03 \\
$\quad$ Low intentional adherence & $55(63.2)$ & $44(51.1)$ & \\
\hline
\end{tabular}

* McNemar's Test 
TABLE III - Level of knowledge about medication before (T0) and after (T1) drug dispensation at the University Pharmacy of the Federal University of Goias, $2013(n=104)$

\begin{tabular}{lccc}
\hline $\begin{array}{l}\text { Level of } \\
\text { knowledge }\end{array}$ & $\begin{array}{c}\text { Before (T0) } \\
\mathbf{n}(\%)\end{array}$ & $\begin{array}{c}\text { After (T1) } \\
\mathbf{n ~ ( \% )}\end{array}$ & $\mathbf{p}^{*}$ \\
\hline Insufficient & $43(41.3)$ & $23(22.1)$ & 0.00 \\
Moderate & $52(50.0)$ & $51(49.0)$ & 0.87 \\
Good & $9(8.7)$ & $30(28.9)$ & 0.00 \\
\hline
\end{tabular}

*McNemar's Test

hand, knowledge about medication is a key component of therapy success, as reported by Angelini et al. (2009) in a study demonstrating that improvement of patients' knowledge on the management of inhaled corticosteroid during an education program was associated with patients' clinical progress.

In this study, although we have not found an increase in adherence to treatment, intentional and unintentional non-adherence behavior has reduced. This finding suggests that dispensing of medication may not enhance adherence to treatment, but may induce a change in the non-adherence behavior, although this change was not statistically significant in our study.

Also, according to a review by Haynes et al. (2013), few dispensation-related interventions have been able to enhance adherence to pharmacotherapy. Additionally, although it is the mostly used indirect instrument to assess adherence, the Morisky scale also used in this study tends to overestimate non-adherence behavior, due to its strict criteria to classify the patient as 'non-adherent' (Leite, Vasconcellos, 2003).

Future studies using different methods for assessing adherence behavior and using a repeated measure design would be of great help in the understanding of the influence of dispensing service on adherence.

Our dispensing system model promoted a high level of satisfaction by patients, which corroborates the findings reported in a similar study conducted in Spain (Guillén et al., 2012).

Studies measuring patient satisfaction with pharmacy services have shown that the human aspects of the services are the most influencing factor on patient satisfaction (Panvelkar, Saini, Armour, 2009). An implication of this finding is that, similarly to other studies in this field, satisfaction may be overestimated in our study, particularly taking into account that the patients interviewed were frequent users of the University Pharmacy.

Results of studies assessing patients' satisfaction with health services should be seen with caution. Meeting or failing to meet patients' expectation of care is an important predictor of patient satisfaction with the service (McKinley et al., 2002). In fact, the high level of satisfaction with medicine dispensing services might be resultant not from their good quality, but from a low expectation by the patients. This is reinforced by a study (Oenning, Oliveira, Blatt, 2011) showing that more than $85 \%$ of patients were highly satisfied with dispensing of medications, even without receiving any information about the correct use of medicines.

Patients' satisfaction with pharmaceutical services is fundamental for the analysis of results, and correlates with the effectiveness of the activities performed. With respect to dispensing services, patients' satisfaction can influence adherence to treatment and patient loyalty to the pharmacy, as highlighted by Guillén et al. (2012).

TABLE IV - Comparison of level of knowledge before (T0) and after (T1) drug dispensation at the University Pharmacy of the Federal University of Goias, $2013(\mathrm{n}=104)$

\begin{tabular}{|c|c|c|c|c|c|c|c|}
\hline \multirow{2}{*}{$\begin{array}{l}\text { Questions about the } \\
\text { drug prescribed }\end{array}$} & \multicolumn{2}{|c|}{ Correct aswers } & \multicolumn{2}{|c|}{ Incorrect answers } & \multicolumn{2}{|c|}{ Did not know } & \multirow[b]{2}{*}{$\mathbf{p}^{*}$} \\
\hline & $\begin{array}{c}\text { T0 } \\
\text { n (\%) } \\
\end{array}$ & $\begin{array}{c}\text { T1 } \\
\text { n (\%) } \\
\end{array}$ & $\begin{array}{c}\text { T0 } \\
\text { n (\%) } \\
\end{array}$ & $\begin{array}{c}\text { T1 } \\
\text { n (\%) } \\
\end{array}$ & $\begin{array}{c}\text { T0 } \\
\text { n (\%) } \\
\end{array}$ & $\begin{array}{c}\text { T1 } \\
\text { n (\%) }\end{array}$ & \\
\hline Therapeutic indication & $91(87.5)$ & $96(92.3)$ & $7(6.7)$ & $5(4.8)$ & $6(5.8)$ & $3(2.9)$ & $0.00 * *$ \\
\hline Dosage & $45(43.3)$ & $71(68.3)$ & $13(12.5)$ & $16(15.4)$ & $46(44.2)$ & $17(16.3)$ & 0.00 \\
\hline Times of administration & $68(65.4)$ & $90(86.6)$ & $12(11.5)$ & $12(11.5)$ & $24(23.1)$ & $2(1.9)$ & $0.01 * *$ \\
\hline Duration of treatment & $70(67.3)$ & $80(76.9)$ & $9(8.7)$ & $5(4.8)$ & $25(24.0)$ & $19(18.3)$ & 0.01 \\
\hline Mode of administration & $83(79.9)$ & $75(73.1)$ & $15(14.4)$ & $9(8.6)$ & $5(4.8)$ & $19(18.3)$ & 0.04 \\
\hline Skipping doses & $79(76.0)$ & $62(59.7)$ & $9(8.6)$ & $7(6.7)$ & $16(15.4)$ & $35(33.6)$ & 0.02 \\
\hline Interactions & $29(27.9)$ & $60(57.7)$ & $15(14.4)$ & $15(14.4)$ & $60(57.7)$ & $29(27.9)$ & 0.01 \\
\hline Adverse effects & $31(29.8)$ & $49(47.1)$ & $15(14.4)$ & $23(22.1)$ & $58(55.8)$ & $32(30.8)$ & 0.21 \\
\hline
\end{tabular}

* Chi-squared Test, ** Exact Fisher's Test 
TABLE V - Patient satisfaction with the drug dispensing service at the University Pharmacy of the Federal University of Goias, 2013

\begin{tabular}{|c|c|c|c|c|c|}
\hline Questionnaire items & $\begin{array}{l}\text { Excellent/Very } \\
\operatorname{good}(\%)\end{array}$ & Good $(\%)$ & Fair/Poor (\%) & Mean & SD \\
\hline 1. Appearance of the Pharmacy* & 79.8 & 18.3 & 1.9 & 4.39 & 0.82 \\
\hline $\begin{array}{l}\text { 2. Promptness of the pharmacist to answer your } \\
\text { questions* }\end{array}$ & 92.2 & 6.8 & 1.0 & 4.67 & 0.65 \\
\hline 3. The pharmacist's relationship with you* & 91.3 & 7.7 & 1.0 & 4.71 & 0.60 \\
\hline $\begin{array}{l}\text { 4. The pharmacist's ability to advise you about problems } \\
\text { that you might have with your medication* }\end{array}$ & 77.9 & 18.3 & 3.8 & 4.33 & 0.98 \\
\hline 5. Promptness of drug prescription service ${ }^{* *}$ & 87.2 & 10.8 & 2.0 & 4.52 & 0.80 \\
\hline 6. Professionalism of the pharmacy staff** & 94.1 & 4.9 & 1.0 & 4.68 & 0.62 \\
\hline $\begin{array}{l}\text { 7. How well the pharmacist explains what your } \\
\text { medication do** }\end{array}$ & 90.2 & 6.8 & 3.0 & 4.57 & 0.86 \\
\hline 8. The pharmacist's interest in your health $* *$ & 84.3 & 11.8 & 3.9 & 4.46 & 0.89 \\
\hline $\begin{array}{l}\text { 9. How well the pharmacist helps you to manage your } \\
\text { medications* }\end{array}$ & 85.4 & 13.6 & 1.0 & 4.48 & 0.76 \\
\hline $\begin{array}{l}10 \text {. The pharmacist's efforts to solve problems that you } \\
\text { have with your medications } * * *\end{array}$ & 89.1 & 9.9 & 1.0 & 4.55 & 0.71 \\
\hline $\begin{array}{l}\text { 11. The responsability taken by the pharmacist for your } \\
\text { drug therapy } * * *\end{array}$ & 85.1 & 10.9 & 4.0 & 4.46 & 0.84 \\
\hline $\begin{array}{l}\text { 12. How well the pharmacist instructs you about how to } \\
\text { take your medications } * * *\end{array}$ & 85.1 & 13.9 & 1.0 & 4.54 & 0.77 \\
\hline 13. Your pharmacy services overall** & 87.2 & 11.8 & 1.0 & 4.47 & 0.74 \\
\hline $\begin{array}{l}\text { 14. How well the pharmacist answers your questions } \\
* * * *\end{array}$ & 87.0 & 12.0 & 1.0 & 4.54 & 0.74 \\
\hline $\begin{array}{l}\text { 15. The pharmacist's efforts to help you improve your } \\
\text { health or stay healthy** }\end{array}$ & 79.4 & 18.6 & 2.0 & 4.41 & 0.86 \\
\hline 16. Courtesy and respect shown by the pharmacy staff** & 92.2 & 7.8 & 0.00 & 4.70 & 0.61 \\
\hline $\begin{array}{l}\text { 17. Privacy of the conversations between you and the } \\
\text { pharmacist ** }\end{array}$ & 80.4 & 14.7 & 4.9 & 4.31 & 0.93 \\
\hline $\begin{array}{l}\text { 18. The pharmacist's efforts to assure that your } \\
\text { medications do what they are supposed to ** }\end{array}$ & 82.4 & 13.7 & 3.9 & 4.39 & 0.87 \\
\hline $\begin{array}{l}\text { 19. How well the pharmacist explains possible side } \\
\text { effects ** }\end{array}$ & 76.5 & 18.6 & 4.9 & 4.32 & 1.03 \\
\hline $\begin{array}{l}20 . \text { The amount of time the pharmacist offers to spend } \\
\text { with you ** }\end{array}$ & 80.4 & 16.7 & 2.9 & 4.35 & 0.86 \\
\hline
\end{tabular}

$*_{\mathrm{n}}=103 ; * *_{\mathrm{n}}=102 ; * * * \mathrm{n}=101 ; * * * * \mathrm{n}=100$

Questionnaires are the most frequently used instruments to assess satisfaction (Guillén et al., 2012). Most of them, however, are self-developed, non-validated tools (Panvelkar, Saini, Armour, 2009), limiting the comparison of their results and utilization in other contexts (Panvelkar, Saini, Armour, 2009). In this study, we used a validated instrument, although the satisfaction with pharmacy services in general, rather than with dispensing services in particular was evaluated (Correr et al., 2009).
The understanding of patients' expectations of the dispensing service and whether the services meet these expectatios need to be explored. Also, future studies should investigate how patient's satisfaction with a service influences the choice of the University Pharmacy, as well as the causes of dissatisfaction by the patients.

Assessing the results of a drug dispensing service is a challenging issue, since the estimation of how drug dispensing affects the therapy main outcome, i.e., the clinical features, is considerably difficult 
(Fernández-1limós, 2002). The knowledge about medications, adherence to treatment and satisfaction with pharmaceutical services may be considered surrogate endpoints in the assessment of dispensing practices. Surrogate endpoints can be measured relatively more easily and reflect the effects of the intervention on clinical endpoints (Wannmacher, 2010). They are used in clinical trials when the clinical endpoints are difficult to be assessed, and also to reduce sample size, time of follow-up and costs of the study (Coutinho, 2002).

\section{CONCLUSION}

These findings suggest that drug dispensing can enhance patients' knowledge about drugs, by providing conditions for a correct the use of medications, in the absence of clinical complications. Additionally, drug dispensing promotes a high level of satisfaction by the patients, with no improvement of adherence behavior to the therapy though.

\section{ACKNOWLEDGEMENTS}

The authors would like to thank the staff of the University Pharmacy, Federal University of Goias, the Instituto Pharmcare Directors Paula Iglésias-Ferreira and Henrique Santos.

\section{CONFLICT OF INTEREST}

The authors declare no conflict of interest.

\section{REFERENCES}

Angelini L, Robles-Ribeiro PG, Carvalho-Pinto RM De, Ribeiro M, Cukier A, Stelmach R. Avaliação de dois anos de um programa educacional para pacientes ambulatoriais adultos com asma. J Bras Pneumol 2009;35(7):618-27.

Angonesi D. Dispensação farmacêutica: uma análise de diferentes conceitos e modelos. Ciênc Saúde Coletiva. 2008;13(Supl):629-40.

Angonesi D, Rennó MUP. Dispensação Farmacêutica : proposta de um modelo para a prática. Ciênc Saúde Coletiva 2011;16(9):3883-91.

Becker ML, Caspers PWJ, Kallewaard M, Bruinink RJ, Kylstra NB, Heisterkamp S, et al. Determinants of potential drug-drug interaction associated dispensing in community pharmacies in the Netherlands. Pharm World Sci 2007;29(2):51-7.
Brasil. Agência Nacional de Vigilância Sanitária. Resolução da Diretoria Colegiada - RDC n ${ }^{\circ} 44$, de 17 de agosto de 2009. Dispõe sobre Boas Práticas Farmacêuticas para o controle sanitário do funcionamento, da dispensação e da comercialização de produtos e da prestação de serviços farmacêuticos em farmácias e drogarias e dá outras providências. D.O.U. - Diário Oficial da União; de 18 de agosto de 2009.

Brasil. Lei n. 5.991, de 17 de dezembro de 1973. Dispõe sobre o controle sanitário do comércio de drogas, medicamentos, insumos farmacêuticos e correlatos, e dá outras providências. Diário Oficial, 19 dez. 1973. Brasília - DF: Imprensa Nacional, 1973. Seção 1, p.13049.

Brasil. Portaria MS n. 3.916, de 30 de outubro de 1998. Política Nacional de Medicamentos. Diário Oficial, 10 nov. 1998. Brasília - DF: Imprensa Nacional, 1998. Seção 1, p.18.

Brasil. Resolução CNS n. 338, de 6 de maio de 2004. Política Nacional de Assistência Farmacêutica. Diário Oficial da União, 20 maio 2004. Brasília - DF: Imprensa Nacional, 2004. Seção 1, p.52.

Buurma H, Smet PAGM De, Hoff OP Van Den, Egberts ACG. Nature, frequency and determinants of prescription modifications in Dutch community pharmacies. Brit J Clin Pharmaco. 2001;52(1):85-91.

Cardoso TC, Sousa JTM, Morais CAE, Prudente LR, Lopes FM, Dewulf N de LS, et al. Serviço de Dispensação: Apresentação de um modelo estruturado em uma Farmácia Universitária. Eletronic J Pharm. 2015;XII(4):73-86.

Centers for Disease Control and Prevention Epi Info [computer program]. Version 3.5.4. Atlanta (GA): Centers for Disease Control and Prevention; 2012.

Chatsisvili A, Sapounidis I, Pavlidou G, Zoumpouridou E, Karakousis V-A, Spanakis M, et al. Potential drug-drug interactions in prescriptions dispensed in community pharmacies in Greece. Pharm World Sci 2010;32(2):187-93.

Conselho Federal de Farmácia. Resolução n 357 de 20 de abril de 2001. Aprova o regulamento técnico das Boas Práticas de Farmácia. D.O.U. - Diário Oficial da União; de 27 de abril de 2001.

Conselho Federal de Farmácia. Resolução n. 480 de 25 de junho de 2008. Dispõe sobre os serviços farmacêuticos na farmáciaescola, pública ou privada, e dá outras providências. D.O.U. - Diário Oficial da União; de 02 de julho de 2008. 
Correr CJ, Pontarolo R, Melchiors AC, Souza RA de P e, Rossignoli P, Fernández-Llimós F. Satisfação dos usuários com serviços da farmácia : tradução e validação do Pharmacy Services Questionnaire para o Brasil. Cad Saúde Pública 2009;25(1):87-96.

Coutinho MSS de A. Desfechos clínicos substitutos e relevantes. O que são e como interpretá-los? Rev Bras Hipertens 2002;9(1):24-8.

Farris KB, Kirking DM. Assessing the quality of pharmaceutical care II. Ann Pharmacother 1993;27(2):215-23.

Fernandes PÁ, Pires MS, Gouvêa AP. Esofagite ulcerativa associada ao uso de alendronato de sódio: achados histopatológicos e endoscópicos. Arq Gastroenterol 2002;39(3):173-6.

Fernández-llimós F, Faus MJ, Caelles N, Espejo J, Gastelurrutia MA, Ibáñez J, et al. Seguimiento farmacoterapéutico y dispensación activa : Diferencias y similitudes. Pharm Care Esp 2002;4:179-85.

Ferreira, TXAM; Prudente LR, Dewulf NLS, Provin MP, Mastroianni PC, Silveira EA, Amaral RG. Medication dispensing as an opportunity for patient counseling and approach to drug-related problems. Braz J Pharm Sci 2016;52(1):151-62.

Foro de Atención Farmacéutica. Dispensación. Farmacéuticos. 2007; Marzo:47-50.

Foro de Atención Farmacéutica. Documento de Consenso. 2008.

Fröhlich SE, Pizzol T da SD, Mengue SS. Instrumento para avaliação do nível de conhecimento da prescrição na atenção primária. Rev Saude Publ. 2010;44(6):1046-54.

Guillén MDM, Rex AH, Labrador RA, Vargas CA, GarciaDelgado P, Martínez-martínez F. Satisfacción delos usuarios de Farmacia comunitaria co um servicio de dispensación pilotado. Ars Pharm 2012;53(2):37-43.

Haynes BR, Ackloo E, Sahota N, MacDonald PH, Yao X. Interventions for enhancing medication adherence. Cochrane Collab 2013;6:1-105.

Iglésias-Ferreira P. Manual de dispensação farmacêutica. 2009.

Indermitte J, Erba L, Beutler M, Bruppacher R, Haefeli WE, Hersberger KE. Management of potential drug interactions in community pharmacies: a questionnaire-based survey in Switzerland. Eur J Clin Pharmacology. 2007;63(3):297-305.
International Pharmaceutical Federation. Aconselhamento, concordância e comunicação: educação inovadora para farmacêuticos. 2009.

Larson LN, Rovers JP, MacKeigan LD. Patient satisfaction with pharmaceutical care: update of a validated instrument. J Am Pharm Assoc 2002;42(1):44-50.

Leite SN, Vasconcellos M da PC. Adesão à terapêutica medicamentosa : elementos para a discussão de conceitos e pressupostos adotados na literatura. Ciênc Saúde Coletiva $2003 ; 8(3): 775-82$.

Margonato FB, Thomson Z, Paoliello MMB. Determinantes nas intoxicações medicamentosas agudas na zona urbana de um município do Sul do Brasil. Cad Saúde Pública 2008;24(2):33341.

McKinley RK, Stevenson K, Adams S, Manku-Scott TK. Meeting patient expectations of care: the major determinant of satisfaction with out-of-hours primary medical care? Fam Pract 2002;19(4):333-8.

Melchiors AC, Correr CJ, Fernández-Llimos F. Tradução e Validação para o Português do Medication Regimen Complexity Index. Arq Bras Cardiol 2007;89(4):210-8.

Morisky DE, Green LW, Levine DM. Concurrent and predictive validity of a self-reported measure of medication adherence. Med Care 1986;24(1):67-74.

Oenning D, Oliveira BV de, Blatt CR. Conhecimento dos pacientes sobre os medicamentos prescritos após consulta médica e dispensação Patient awareness about drugs prescribed after medical appointment and prescription. Ciênc Saúde Coletiva 2011;16(7):3277-83

Panvelkar PN, Saini B, Armour C. Measurement of patient satisfaction with community pharmacy services: a review. Pharm World Sci 2009;31(5):525-37.

PCNE. Pharmaceutical Care Network Europe Foundation. Classification for Drug related problems. Version 6.2. 2010.

Pharmasoftware, 2013. Pharmacie. Goiânia, GO: Pharmasoftware. 2013.

Ponnusankar S, Surulivelrajan M, Anandamoorthy N, Suresh B. Assessment of impact of medication counseling on patients ' medication knowledge and compliance in an outpatient clinic in South India. Patient Educ Couns. 2004;54(1):55-60. 
Sánchez A de las MM. Medication errors in a Spanish community pharmacy : nature, frequency and potential causes. Int J Clin Pharm 2013;35(2):185-9.

Sewitch MJ, Barkun A, Bitton A, Wild GE, Cohen A, Dobkin PL. Patient nonadherence to medication in inflammatory bowel disease. Am J Gastroenterology 2003;98(7):1535-44.

Silva T da, Schenkel EP, Mengue SS. Nível de informação a respeito de medicamentos prescritos a pacientes ambulatoriais de hospital universitário. Cad Saúde Pública 2000;16(2):449-55.
Soares L, Diehl EE, Leite SN, Farias MR. A model for drug dispensing service based on the care process in the Brazilian health system. Braz J Pharm Sci 2013;49(1):107-16.

StataCorp. 2011. Stata Statistical Software: Release 12. College Station, TX: StataCorp LP; 2011.

Wannmacher L. Condutas Baseadas em Evidências sobre Medicamentos Utilizados em Atenção Primária à Saúde. Brasília, DF: Ministério da Saúde; 2010. p. 1-7.

Received for publication on $02^{\text {nd }}$ November 2016 Accepted for publication on $15^{\text {th }}$ February 2018 